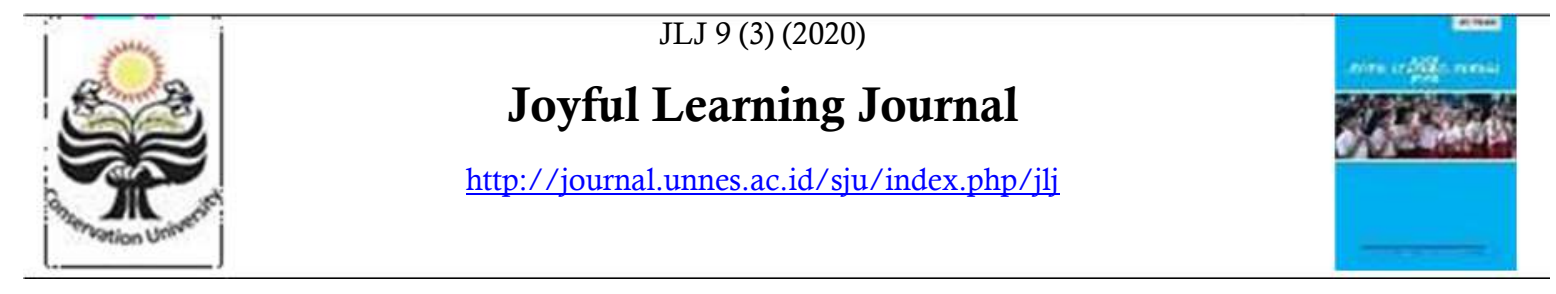

\title{
HUBUNGAN POLA ASUH ORANG TUA DENGAN SIKAP SOSIAL SISWA SD
}

\section{Susi Dwi Astuti ${ }^{\bowtie}$,Dra. Sri Sami Asih, M.Kes}

Jurusan Pendidikan Guru Sekolah Dasar, Fakultas Ilmu Pendidikan, Universitas Negeri Semarang, Indonesia

\section{Info Artikel}

Sejarah Artikel:

Diterima Juli 2020

Disetujui Agustus

2020

Dipublikasikan

September 2020

Keywords

parenting styles; social

attitudes

\begin{abstract}
Abstrak
Tujuan penelitian ini adalah untuk menguji hubungan antara pola asuh orang tua dengan sikap sosial siswa kelas IV SDN Gugus Werkudara Kecamatan Petanahan Kebumen. Jenis penelitian ini adalah penelitian korelasi. Populasi dalam penelitian ini adalah siswa kelas IV SDN Gugus Werkudara Kecamatan Petanahan Kebumen penelitian ini berjumlah 158 siswa. Teknik pengambilan sampel menggunakan Proportional Random Sampling sebanyak 111 siswa. Teknik pengumpulan data menggunakan angket, dokumentasi, dan wawancara. Uji instrumen dilakukan dengan uji validitas dan reliabilitas. Sedangkan analisis data dalam penelitian ini terdiri darianalisis statistik deskriptif, analisis uju prasyarat data, dan analisis data akhir menggunakan korelasi Product Moment, dan koefisien determinasi. Hasil penelitian menunjukkan bahwa ada hubungan yang positif dan signifikan antara pola asuh orang tua dengan sikap sosial siswa, kontribusi variabel pola asuh orang tua dengan sikap sosial tersebut termasuk dalam kategori kuat.
\end{abstract}

\section{Abstract}

The purpose of this research was to examine the correlation between Parenting Styles with Social Attitudes of the fourth grade students in Cluster Werkudara Elementary School Petanahan Kebumen. The population of this study was the fourth grade students in Cluster Werkudara Elementary School Petanahan Kebumen in the number of 158 students. The sampling technique used proportional random sampling in the number of 111 students. Data collection techniques using questionnaires, documentation, and interviews. While, the data analysis and final data analysis technique in this study consisted of descriptive statistical analysis, prerequisite test analysis and final data analysis using a simple correlation test and determination test. The resultshowthere was a positive and significant relationship between parenting styles with students' social attitudes, the contribution of parenting styles to social attitudes are included in the strong category. 


\section{PENDAHULUAN}

Program Penguatan Pendidikan Karakter dalam membentuk pribadi siswa yang lebih baik dituangkan Permendikbud Nomor: 20 Tahun 2018 tentang Penguatan Pendidikan Karakter yang bertujuan untuk memperkokoh karakter sebagai bentuk harmonisasi olah hati, olahrasa, olahraga, dan olah pikir dengan melibatkan masyarakat sebagai bagian dari Gerakan Nasional Revolusi Mental (GNRM). Di masa yang akan datang, siswa dihadapkan pada kondisi lingkungan yang bervariatif, dengan demikian adanya penguatan pendidikan karakter, siswa diharapkan memiliki sikap yang baik.Tentu menjadi sorotan utama bahwa pembentukan pendidikan karakter sangat penting. Terlebih program Penguatan Pendidikan karakter mencakup penanaman 18 nilai- nilai karakter yakni religius, disiplin, jujur, toleransi, etos kerja keras, kreativitas, mandiri, demokratis, cinta tana air, rasa ingin tahu, semangat kebangsaan, bersahabat, menghargai prestasi, gemar membaca, cinta damai, peduli lingkungan peduli sosial, tanggung jawab.Pendidikan seorang anak tidak hanya terjadi di lingkungan sekolah artinya tidak terlepas dari lingkungan keluarga dan lingkungan masyarakat. Peraturan yang menjelaskan proses pendidikan tidak hanya terjadi di sekolah yaitu Undang-Undang Nomor 13 Tahun 2005 menenerangkan bahwa "Jalur pendidikan terdiri atas pendidikan formal, nonformal, dan informal yang dapat saling melengkapi dan memperkaya”.

Tridhonanto (2014:5) menjelaskan bahwa pola asuh orang tua adalah suatu keseluruhan interaksi orang tua dan anak, dimana orang tua yang memberikan dorongan bagi anak dengan mengubah tingkah laku, pengetahuan, dan nilai - nilai yang dianggap paling tepat bagi orang tua agar anak bisa mandiri, tumbuh serta berkembang secara sehat dan optimal, memiliki rasa percaya diri, memiliki rasa sifat ingin tahun, bersahabat, dan berorientasi untuk sukses.Menurut Tiara (2019:26) sikap sosial yaitu ekspresi seseorang dalam menyikapi kehidupan sosial yang memiliki pengaruh penting dalam kehidupan karena dalam menjalani hidup manusia tidak bisa menggantungkan kebutuhanya secara mandiri namun perlu bantuan orang lain. Peran orang tua dan respon dari lingkungan sangat diperlukan bagi anak sebagai "penguat" untuk setiap perilaku yang telah dialaminya. Ketika manusia bersosial maka perlu adanya karakter sosial yang baik, sehingga tingkah laku atau tindakanya dapat diterima oleh lingkungan. Begitupun dengan sikap tanggung jawab dan percaya diri, apabila seorang tersebut memmpunya sikap yang baik orang lain pasti akan cenderung percaya.

Berdasarkan informasi yang diperoleh peneliti melalui wawancara dengan guru kelas IV SDN Gugus Werkudara Kecamatan Petanahan Kebumen adalah sikap sosial pada aspek tangung jawab dan percaya diri dengan kategori cukup.Sebagian siswa yang mengandalkan bantuan teman ketika mengerjakan tugas, terdapat siswa yang mencontek ketika mengerjakan ulangan, dan terdapat siswa yang belum mengerjakan PR sehingga sikap sosial pada siswa dikatakan cukup terutama pada sikap tanggung jawab dan percaya diri siswa dalam mengikuti pembelajaran.

Guru harus selalu memancing siswa untuk aktif dan lebih percaya diri. Perkembangan sikap pada anak dipengaruhi oleh cara orang tua mengasuh dan mendidik anak. Pola asuh orang tua yang baik akan mendorong sikap anak sehingga perkembangan akan optimal, sedangkan pola asuh yang tidak baik akan menghambat perkembangan sikap pada anak.

Penelitian yang dilakukan oleh Manalu Effendi dan Supianto Lestari pada tahun 2016 "Hubungan Pola Asuh Orang Tua terhadap Sikap Sosial Siswa". Hasil Penelitianya menunjukan; Penerapan pola asuh orang tua cenderung pada jenis pola asuh demokratis dimana orang tua memberikan kebebasan pada anak namun tetap memberi pengawasan. Varians yang terjadi pada variabel pola asuh orang tua yaitu $56 \%$ dan $44 \%$ perubahan yang terjadi pada sikap sosial siswa sebesar $56 \%$ dipengaruhi oleh pola asuh orang tua. Orang tua memiliki pengaruh terhadap tingkah laku anaknya juga sikap sosial di sekolah.

Penelitian yang dilakukan oleh Kustlah Sunarty Tahun 2016 dengan judul " Hubungan Pola Asuh Orang Tua dan Kemandirian Anak". Hasil penelitianya menunjukan bahwajenis pola asuh orang tua yang memiliki korelasi yang kuat dalam meningkatkan kemandirian anak yaitu pola asuh orang tua positif, dan demokratis.

Penelitian yang dilakukan oleh Setiawati Eka Tahun 2015 dengan judul "Pengaruh Pola Asuh terhadap Kedisiplinan Belajar Siswa". Hasil penelitianya menunjukkan indeks indikator variabel pola asuh paling rendah pada indikator positif "adanya hukuman pada setiap pelanggaran" sedangkan pada kedisiplinan belajar indeks paling rendah yaitu indikator positif "menggunakan waktu belajar di rumah secara optimal". Hasil penelitianya menunjukkan bahwa kedisiplinan belajar akan meningkat apabila orang tua meningkatkan kualitas pola asuh dengan memberikan pola asuh yang tepat.

Penelitian yang dilakukan oleh Simon Njogu Njagi dan DR Jonathan M Mwania 
(2017) dengan judul "Parenting Styles as Predictors of Drop Out Rate Among Selected Public Secondary School Students in Embu Country, Kenya". Hal tersebut membuktikan bahwa pola pengasuhan permisif paling besar pengaruhnya dalam tingkat anak putus sekolah dengan faktor 1,798 pada tingkat signifikan 5\%. Dapat disimpulkan bahwa pola pengasuhan memainkan peran utama dalam memprediksi tingkat siswa putus sekolah.

Berdasarkan latar belakang tersebut, tujuan dari penelitian ini adalahmenguji hubungan antara pola asuh orang tua dengansikap sosial siswa kelas IV SDN Gugus Werkudara Kecamatan Petanahan Kebumen.

\section{METODE PENELITIAN}

Penelitian ini merupakan penelitian kuantitatif jenis penelitian korelasi. Arikunto (2010) menjelaskan bahwa penelitian korelasi adalah penelitian yang dilakukan untuk menemukan ada atau tidaknya hubungan. Populasi dalam penelitian ini adalah siswa kelas IV SDN Gugus Werkudara Kecamatan Petanahan Kebumen. Penelitian ini dilaksanakan di SDN 1 Munggu, SDN 1 Ampelsari, SDN 3 Karagrejo, SDN Tegalretno, SDN 1 Karanggadung.

Teknik pengambilan sampel menggunakan teknik proportional random sampling yaitu sebanyak 111 siswa.Variabel dalam penelitian ini terdiri atas variabel bebas dan variabel terikat. Variabel bebas adalah pola asuh orang tua, sedangkan variabel terikat adalah sikap sosial siswa.

Teknik pengumpulan data dengan menggunakan angket, wawancara dan dokumentasi. Angket digunakan untuk mengumpulkan data pola asuh orang tua, dan sikap sosial, sedangkan wawancara digunakan untuk mengetahui informasi awal berupa permasalahan yang terjadi di sekolah berkaitan dengan pembelajaranserta dokumentasi digunakan untuk mendokumentasi nilai sikap aspek sikap sosial. Sebelum instrumen penelitian digunakan, maka dilakukan uji coba. Selanjutnya peneliti menguji validitas dan relabilitas instrumen tersebut. Teknik analisis data yang digunakan pada penelitian ini adalah: (1)analisis statistik deskriptif; (2) transformasi data; (3) analisis pengujian hipotesis menggunakan korelasi sederhana, dan koefisien determinasi

\section{HASIL DAN PEMBAHASAN}

Hasil analisis statistik deskriptif digunakan untuk mendeskripsikan secara rinci setiap variabel penelitian. Pembahasan variabel menggunakan data kuantitatif, yaitu data yang diolah berbentuk angka atau skor yang kemudian ditafsirkan secara deskriptif. Pengkategorian data variabel dibedakan menjadi empat kategori, variabel pola asuh orang tua, dan sikap sosial yaitu sangat baik, baik, cukup baik, dan kurang baik.

\section{Hasil Analisis Deskriptif Pola Asuh Orang Tua (X1)}

Jumlah Pertanyaan dalam angket pola asuh orang tua terdiri atas 25 item. Pola Asuh Orang Tua siswa kelas IV SDN Gugus Werkudara Kecamatan Petanahan Kebumen, dapat dilihat pada tabel berikut:

Tabel 1. Distribusi Frekuensi Absolut dan Relatif Pola Asuh Orang Tua

\begin{tabular}{ccc}
\hline Sub Variabel & \multicolumn{2}{c}{ Frekuensi } \\
& Absolut & Relatif(\%) \\
\hline Pola & 38 & $34 \%$ \\
Asuh & & \\
Otoriter & 24 & $22 \%$ \\
Pola & & \\
Asuh & 49 & $44 \%$ \\
Permisif & & \\
Pola & & \\
Asuh & & \\
Demokratis & & \\
\hline
\end{tabular}

Sumber : Data penelitian yang diolah pada tahun 2020

Dari hasil perhitungan tersebut, dapat disimpulkan bahwa secara umum pola asuh yang diterapkan orang tua siswa kelas IV SD Negeri Gugus Werkudara Kecamatan Petanahan Kebumen adalah pola asuh demokratis. Namun, selain pola asuh demokratis terdapat pula orang tua yang menerapkan pola asuh otoriter dan pola asuh permisif.

\section{Hasil Analisis Sikap Sosial (Y)}

Jumlah Pertanyaan dalam angket Sikap Sosial terdiri atas 30 item. Sikap Sosial siswa kelas IV SDN Gugus Werkudara Kecamatan Petanahan Kebumen, dapat dilihat pada tabel berikut

Tabel 2 Kategori Sikap Sosial

\begin{tabular}{ccccc}
\hline $\begin{array}{c}\text { Interval } \\
\text { Skor }\end{array}$ & $\begin{array}{c}\text { Katego } \\
\text { ri }\end{array}$ & $\begin{array}{c}\text { Freku } \\
\text { ensi }\end{array}$ & $\begin{array}{c}\text { Present } \\
\text { ase (\%) }\end{array}$ & Rata- rata \\
\hline $82-100$ & $\begin{array}{l}\text { Sangat } \\
\text { Baik }\end{array}$ & 32 & $29 \%$ & 76,1 \\
& Baik) \\
$63-81$ & Baik & 69 & $62 \%$ & \\
$44-62$ & $\begin{array}{l}\text { Cukup } \\
25-43\end{array}$ & 10 & $9 \%$ & \\
& $\begin{array}{l}\text { Baik } \\
\text { Kurang } \\
\text { Baik }\end{array}$ & 0 & $0 \%$ & \\
Jumlah & $\mathbf{1 1 1}$ & $100 \%$ & \\
\hline
\end{tabular}

Sumber : Data penelitian yang diolah pada tahun 2020 


\section{Uji Prasyarat Analisis Uji Normalitas}

Uji Normalitas digunakan untuk memastikan data setiap variabel yang dianalisis berdistribusi normal.Penelitian ini menguji normalitas menggunakan One Sample Kolmogorov-Smirnov Test berbantuan SPSS. Berdasarkan hasil uji normalitas didapatkan nilai pada variabel pola asuh orang tua sebesar 0,975 , dan variabel sikap sosial sebesar 0,842 . Kedua variabel tersebut memiliki nilai signifikansi lebih besar dari 0,05. Maka, dapat diketahui bahwa data kedua variabel tersebut berdistribusi normal.

\section{Uji Linieritas}

Uji linieritas variabel pola asuh orang tua dengan sikap sosial siswa diperoleh nilai signifikansi Deviation from Linearity 0,671 > 0,05 maka dapat disimpulkan bahwa hubungan pola asuh orang tua dengan sikap sosial siswa dinyatakan linier.

\section{Analisis Hipotesis Korelasi Sederhana}

Uji korelasi sederhana dalam penelitian ini menggunakan uji korelasi product moment dengan bantuan program SPSS. Hasil perhitungan dapat dilihat pada tabel berikut;

Tabel 3 Hasil Korelasi Sederhana antara Pola Asuh Orang Tua dengan Sikap Sosial Siswa

\begin{tabular}{|c|c|c|c|}
\hline \multicolumn{4}{|c|}{ Correlations } \\
\hline & & $\mathrm{X} 1$ & $\mathrm{Y}$ \\
\hline \multirow[t]{2}{*}{$\mathrm{X} 1$} & Pearson Correlation & 1 & $.645^{*}$ \\
\hline & Sig. (2-tailed) & & .000 \\
\hline & $\mathrm{N}$ & 111 & 111 \\
\hline \multirow[t]{3}{*}{$\mathrm{Y}$} & Pearson Correlation & $.645^{*}$ & 1 \\
\hline & Sig. (2-tailed) & .000 & \\
\hline & $\mathrm{N}$ & 111 & 111 \\
\hline
\end{tabular}

Tabel 3 menunjukkan bahwa angka indeks korelasi( $\left.\mathrm{r}_{\text {hitung }}\right)$ sebesar 0,645 yang artinya ada korelasi atau hubungan dengan tingkat kuat pola asuh orang tua dengan sikap sosial siswa. Hasil uji signifikansi menunjukkan bahwa $\mathrm{Ha}_{1}$ diterima karena $\mathrm{r}_{\text {hitunglebih }}$ besar dari $\mathrm{r}_{\text {tabel }}$ $(0,645>0,185)$.

\section{Koefisien Determinasi}

Tabel 4 Hasil Uji Determinasi Pola Asuh Orang Tua dengan Sikap Sosial Siswa

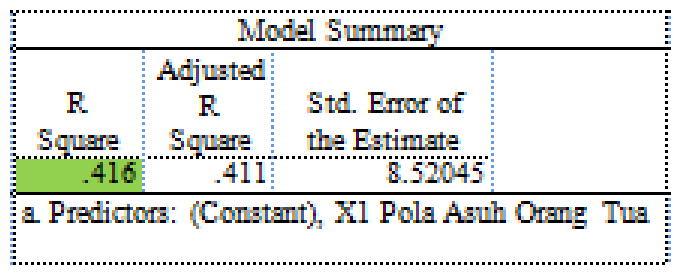

Sumber: Data penelitian yang diolah menggunakan SPSS 21 pada tahun 2020
Berdasarkan tabel 4.60 tersebut menunjukkan bahwa nilai $\mathrm{R}^{2}$ sebesar $0,416 \mathrm{x}$ $100 \%=41,6 \%$. Artinya sumbangan hubungan pola asuh orang tua dengan sikap sosial siswa sekitar $41,6 \%$ sedangkan sisanya $58,4 \%$ dipengaruhi oleh faktor lain yang tidak diteliti.

\section{Hubungan Pola Asuh Orang Tua dengan Sikap Sosial}

Tabel 3 dan 4 menunjukkan bahwa angka indeks korelasi( (hitung ) sebesar 0,645 yang artinya ada korelasi atau hubungan dengan tingkat kuat pola asuh orang tua dengan sikap sosial siswa. Hasil uji signifikansi menunjukkan bahwa $\mathrm{Ha}_{1}$

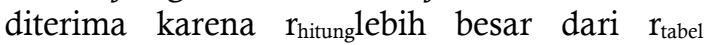
$(0,645>0,185)$. Nilai R Square adalah 0,416 Rsquare dapat disebut sebagai koefisien determinasi yang berarti dalam hal ini 41,6\% sikap sosial dipengaruhi oleh pola asuh orang tua, sisanya dipengaruhi oleh faktor lain.

Berdasarkan perhitungan tersebut maka dapat disimpulkan bahwa terdapat hubungan yang positif dan signifikan antara pola asuh orang tua dengan sikap sosial siswa kelas IV SDN Gugus Werkudara Kecamatan Petanahan Kebumen .Artinya, pola asuh orang tua memiliki kontribusi dalam meningkatkan sikap sosial siswa. Siswa yang memiliki pola asuh baik akan berpengaruh terhadap sikap yang baik. Begitupun sebaiknya, siswa yang mendapatkan pola asuh kurang baik maka sikap sosial siswa berdampak kurang baik pula.

Penelitian yang dilakukan oleh Widhiasih, Sumilah, dkk Tahun 2017 dengan judul "Pengaruh Pola Asuh Orang Tua terhadap Hasil Belajar IPS" Hasil penelitianya yaitu pola asuh yang diterapkan siswa kelas IV SDN SeGugus Kresna Kecamatan Semarang memiliki kecenderungan dengan pola asuh demokratis sebanyak $88,3 \%$. Dengan demikian terdapat pengaruh yang positif dan signifikan antara pola asuh orang tua terhadap hasil belajar IPS

Penelitian yang sejalan dengan penelitian ini adalah penelitian yang dilakukan oleh Eka Rahma dan Yusmansyah tahun 2017 dengan judul "Hubungan Pola Asuh Orang Tua dengan Kemandirian Belajar Siswa". Analisis dalam penelitian ini menggunakan korelasi parsial berdasarkan keempat pola asuh orang tua, pola asuh demokratis memiliki hubungan yang paling besar dengan kemandirian belajar dan hasil indeks korelasi sebesar $r_{\text {hitung }}=0,633>r_{\text {tabel }}$ $=163, p=0,000<p=0,05$.

Dengan demikian orang tua yang menerapkan pola asuh yang tepat maka kemandirian belajar anak akan semakin baik.

Penelitian oleh Syamsu Rijal dan Suhaedir Bachtiartahun 2015 dengan judul "Hubungan antara sikap, kemandirian belajar, dan gaya belajar dengan hasil belajar kognitif 
siswa". Hasil penelitian menunjukkan bahwa terdapat hubungan yang positif antara 1) sikap siswa dengan hasil belajar kognitif Biologi; 2) kemandirian belajar siswa dengan hasil belajar kognitif biologi; 3) gaya belajar siswa dengan hasil belajar kognitif Biologi; 4) sikap, kemandirian dan gaya belajar siswa dengan hasil belajar kognitif Biologi.

Penelitian yang dilakukan oleh Neolaka Amos dan Yasin Mahmudin Tahun 2019 dengan judul "Development of Social Studies Learning Model Based on Local Wisdom in Improving Students' Knowledge and Social Attitude". Hasil penelitianya adalah 1) analisis data penilaian instrumen sikap sosial dari 20 item pernyataan menunjukkan nilai $\mathrm{CRV}>0$. Nilai CVR dari 2 pernyataan item berjumlah 0,33 dan 28 item pernyataan berjumlah 1,00 yang artinya masing-masing item dinyatakan baik. 2) Uji $\mathrm{T}$ pengetahuan dan sikap sosial siswa menunjukan bahwa hasil tes pengetahuan dari kelompok eksperimen lebih tinggi dari kelompok kontrol, artinya penggunaan bahan ajar berbasis kearifan lokal lebih efektif dari pada bahan pengajaran konvensional meningkatkan pengetahuan siswa dan sikap sosial.

Penelitian yang dilakukan oleh Suardiman dan Setiawan Ari Tahun 2018 dengan judul "Assesment of the social attitude of primary school students". Hasil penelitianya yaitu Aspek sikap jujur, disiplin, percaya diri dalam kategori (A) sedangkan aspek sikap tanggung jawab, peduli, dan sopan dalam kategori (B). Hal tersebut menunjukkan bahwa sebagian siswa memiliki sikap sosial sangat baik dan baik.

\section{SIMPULAN}

Terdapat hubungan yang positif dan signifikan antara pola asuh orang tua dengan sikap sosial siswa kelas IV SDN Gugus Werkudara Kecamatan Petanahan Kebumen. Hal ini ditunjukkan dengan $r_{\text {hitung }}$ lebih besar dari $r_{\text {tabel }}$ yaitu $0,645>0,185$ pada taraf signifikansi $5 \%$ termasuk kategori kuat, serta memberikan kontribusi atau sumbangan dengan sikap sosial sebesar $41,6 \%$.

\section{UCAPAN TERIMAKASIH}

Ucapan terima kasih disampaikan kepada:Dra. Sri Sami Asih, M.Kes, . sebagai dosen pembimbing pertama, Dr. Sri Sulistyorini, M.Pd sebagai Mitra Bestari I, dan Dr. Eko Purwanti, M.Pd, sebagai Mitra Bestari II, yang telah memberikan bimbingan dan masukan dalam penyusunan manuskrip.

\section{DAFTAR PUSTAKA}

Arikunto, Suharsimi. 2013. Prosedur Penelitian: Suatu Pendekatan Praktik. Jakarta: Rineka Cipta

Effendi Manalu, 2016. Hubungan Pola Asuh Orang Tua terhadap Sikap Sosial Siswa. Jurnal Handayani PGSD FIP UNIMED. Vol 5. No.1Tahun 2016.

Eka Rahma dan Yusmansyah. 2017. Hubungan Pola Asuh Orang Tua dengan Kemandirian Belajar Siswa. Vol. 5 No. 6

Fatimah, Enung. 2010. Psikologi Perkembangan. Bandung: CV Pustaka Setia.

Kustlah Sunarty, 2016. Hubungan Pola Asuh Orang Tua dan Kemandirian Anak. Makasar: Jurnal Ilmiah Bimbingan dan Konseling. Vol.2 No.3 Tahun 2016

Neolaka Amos dan Yasin Mahmudin. 2019. Development of Social Studies Learning Model Based on Local Wisdom in Improving Students' Knowledge and Social Attitude. Vol. 12 No. 3

Peraturan Menteri Pendidikan dan Kebudayaan Nomor 20 Tahun 2018 tentang Penguatan Pendidikan Karakter, Jakarta: Depdiknas.

Setiawati Eka. 2015. Pengaruh Pola Asuh terhadap Kedisiplinan Belajar Siswa. Journal of Elementary Education, Vol. 1 No.

Simon Njogu Njagi dan DR Jonathan M Mwania. 2017. Parenting Styles as Predictors of Drop Out Rate Among Selected Public Secondary School Students in Embu Country, Kenya

Suardiman dan Setiawan Ari. 2018. Assesment of the social attitude of primary school students. Vol. 4 No.1

Susanto, Ahmad. 2016. Teori Belajar dan Pembelajaran di Sekolah Dasar. Jakarta: Prenada Media Grup

Syamsu Rijal dan Suhaedir Bachtiar. 2017. Hubungan antara sikap, kemandirian belajar, dan gaya belajar dengan hasil belajar kognitif siswa. Jurnal BIOEDUKATIKA, Vol. 3 No. 2, Hal 15-20. 
Tiara, S.K \& Sari, E.Y. (2019). Analisis Teknik Penilaian Sikap Sosial Siswa dalam Penerapan Kurikulum 2013 di SDN 1 Watulimo. Jurnal Pendidikan Dasar, 11(1), 21-30.
Tridhonanto, A1. 2014. Mengembangkan Pola Asuh Demokratis. Jakarta: PT Elex Media Komputindo.

Widhiasih, Sumilah, dkk. 2017. Pengaruh Pola Asuh Orang Tua terhadap Hasil Belajar IPS. Vol.7 No.2 